\title{
Understanding the ecology of tree-seedling growth in dry tropical environment: a management perspective
}

\author{
Rahul Bhadouria $^{1} \cdot$ Rishikesh Singh $^{2} \cdot$ Pratap Srivastava $^{1} \cdot$ Akhilesh Singh Raghubanshi $^{2}$ \\ ${ }^{1}$ Ecosystems Analysis Laboratory, Department of Botany, Institute of Science, Banaras Hindu University, Varanasi 221005, India \\ ${ }^{2}$ Institute of Environment and Sustainable Development (IESD), Banaras Hindu University, Varanasi, Uttar Pradesh 221005, India
}

Received: 15 May 2016/Revised: 24 July 2016/Accepted: 2 August 2016/Published online: 19 August 2016

(C) Joint Center on Global Change and Earth System Science of the University of Maryland and Beijing Normal University and Springer-Verlag Berlin Heidelberg 2016

\begin{abstract}
The dry tropical forests are among the most vulnerable ecosystems of the world and, however, are relatively understudied. These forests provide various ecosystem services, and are progressively being converted into patches of dry scrubs, savanna and marginal cropland systems, due to various anthropogenic perturbations. Soils of these regions are relatively nutrient poor with a patchy nutrient and water distribution pattern. Therefore, the variability in these natural resources imposed by the present climate change scenario may affect the forest plant community of dry tropics via its impact on seedling growth and recruitment. Seedlings are considered as the most sensitive stage of plant lifecycle, and therefore, understanding of seedling regeneration may help in restoration of forest ecosystems. Seedling growth is majorly regulated by various naturally occurring resources (such as light, water, nutrient, etc.) and disturbances (such as defoliation, grass competition, fire, etc.). Therefore, efforts on the regeneration of these forest systems are highly necessitated. In the present study, we critically reviewed the studies on seedling survival and growth under different resource and disturbance regimes with a special focus to dry tropical environment. We found that water, light, nutrients, herbivory, and grass competition majorly regulates recruitments, growth, and establishment of the tree seedling in dry tropical environment. Most of the studies are limited to observe the effect of one or two factors over the seedling survival and growth. However, the resources and disturbances may have an interactive effect over seedling growth. Therefore, studies encompassing the interactions
\end{abstract}

Akhilesh Singh Raghubanshi asr.iesd.bhu@gmail.com of various growth factors (resources and disturbances) under different climatic conditions are urgently needed for the successful regeneration of tree seedlings and for the restoration of plant community. Moreover, it will improve our ability to manage the tropical vegetation under changing climatic scenario.

Keywords Dry tropical forests - Growth regulators . Interaction $\cdot$ Resource $\cdot$ Seedling $\cdot$ Survival $\cdot$ Tree

\section{Introduction}

Globally, tropical forests harbor considerably higher genetic, species, and ecosystem-level diversity, and play an important role in global C cycle as compared to temperate forests (Hubbell and Foster 1983; Singh and Singh 1988; Raven et al. 1993). These forests share only $7 \%$ of total land surface of the Earth while supports $50 \%$ of the plant life forms (Wilson 1988). In addition to their higher species richness, these forests provide several ecosystem services for the well-being of human and other animals. Moreover, these forests have a considerable impact on the global carbon cycle due to its higher net primary productivity (Raven et al. 1993). Tropical forest is categorized as moist and dry tropical forests, depending upon the annual temperature and precipitation regimes. Among tropical forests, tropical dry forest shares about $42 \%$ of the total global coverage (Holdridge 1967; Murphy and Lugo 1986), which represents the most vulnerable and least protected ecosystems of the Earth's land surface (Murphy and Lugo 1986). These forests are mostly located in India, Kenya, Zimbabwe, Egypt, and Brazil (Raven et al. 1993). In this 
review, we critically reviewed the studies of the dry tropical environment due to its importance in global climate change by considering dry tropical forests of India as a representative of such environment.

In India, dry deciduous forests represent the largest forest type (Singh and Singh 1988), and share about $38.2 \%$ of the total forested area (MoEF 1999). These forests occur in comparatively warm to hot climate having evaporation to precipitation ratio $(e / r)$ of more than 1 (Raven et al. 1993). These regions have a prominent seasonality in temperature and rainfall pattern with a regular drought period of 2-6 months in each year (Murphy and Lugo 1986). The mean annual temperature in dry tropical region is more than $17{ }^{\circ} \mathrm{C}$ (Holdridge 1967; Olivares and Medina 1992; Crews et al. 1995; Dirzo et al. 2011). Comparatively high human population density in dry tropical region as than other regions of the world is also one of the characteristic features of these ecosystems (Murphy and Lugo 1986; Sanchez-Azofeifa et al. 2005). Currently, the dry tropical vegetation is experiencing severe degradation due to increased human interferences (Jha and Singh 1990; Chazdon 2003; Morris 2010; Popradit et al. 2015) and consequent ingression of invasive plant species (Sharma et al. 2005; Raghubanshi and Tripathi 2009). These events have led to a progressive conversion of species-abundant dry tropical forest into species-poor dry deciduous scrub, savanna, grasslands, and adjacent cropland systems (Fig. 1), since past several decades (Champion and Seth
1968; Jha and Singh 1990; Singh et al. 1991). The vegetation of dry tropical environment can be better considered as a mixed form of closed-to-open forests and savanna ecosystems. Therefore, in the preceding section of the review, we have considered the studies conducted for dry tropical forests as well as savanna vegetation of the world with a focus on the studies from India.

Dry tropical ecosystems experience a more arduous and less anticipated environment, thus resulting into its proneness to environmental stress during the successional process of plant community development (Murphy and Lugo 1986). In India, most of the dry tropical vegetation occur in nutrient poor soils (Singh et al. 1989), which may have a tendency to conserve the nutrients (via immobilization in microbial biomass) and act as potential C sinks (Srivastava et al. 2016). Forest composition in such soils consists of species varying in their life history traits, such as leaf types (i.e., broad-leaved species and fine-leaved species), successional statuses (i.e. pioneer and non-pioneer), $\mathrm{N}_{2}$ fixation ability, tree size, and habitat preference (Chaturvedi et al. 2011). These species, therefore, respond differently to the resource availability and disturbance gradients (Chapin et al. 2003). For example, pronounced spatio-temporal variability in resources, such as light, nutrient (Raghubanshi et al. 1990), and water (Kottek et al. 2006; Singh and Ranade 2010; Chaturvedi et al. 2011, 2013, 2014), as well as the disturbances, such as herbivory (Staver et al. 2009; Chaturvedi et al. 2012;
Fig. 1 Current ecological scenario of dry tropical forest ecosystems

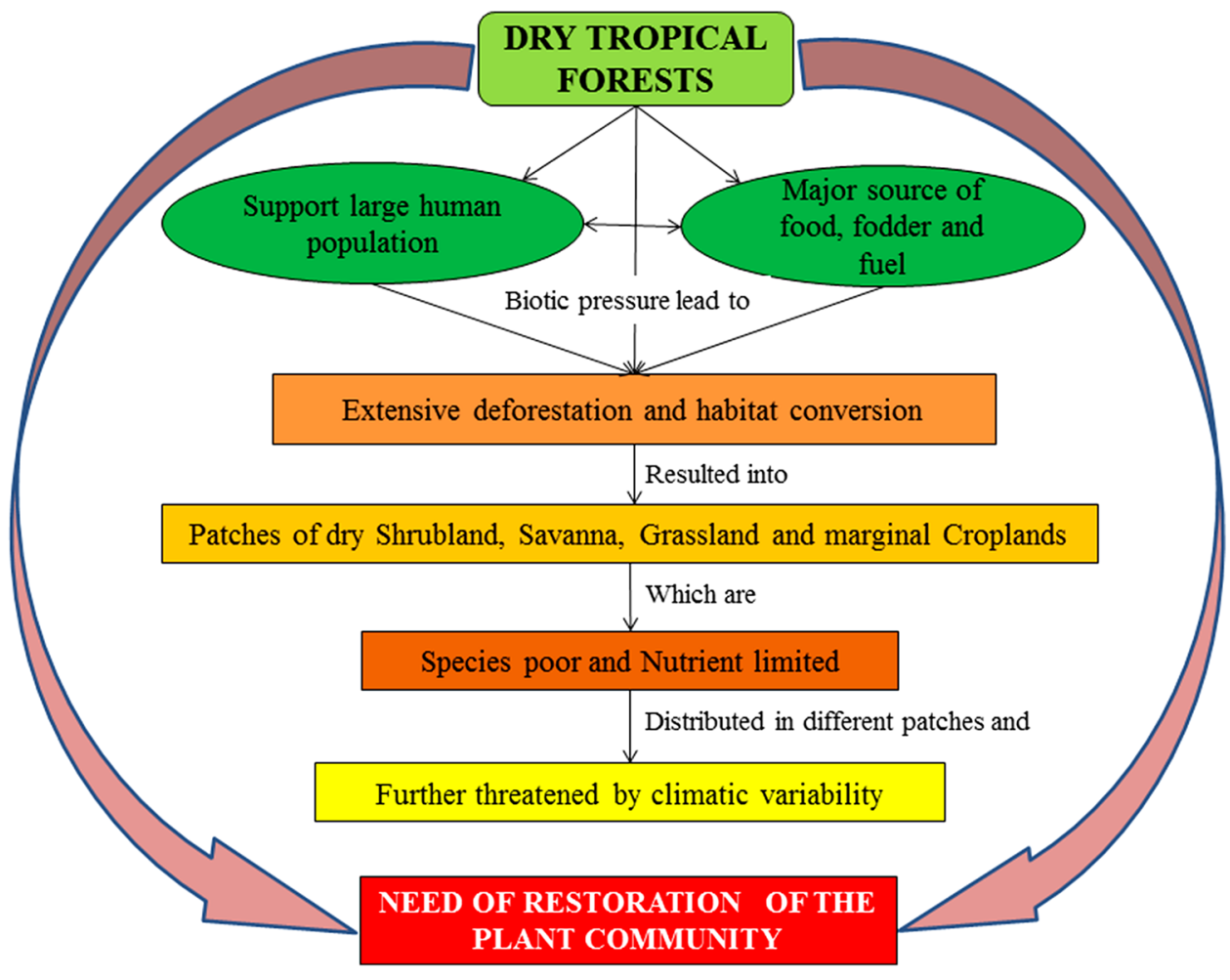


Juan-Baeza et al. 2015) and fire (Russell-Smith et al. 2003; Otterstrom and Schwartz 2006), has been reported in dry tropical environment. Therefore, a better understanding of tree plants, especially seedling response under varying environmental conditions (i.e., resources and disturbances), may hold considerable importance in the restoration of these degrading forest ecosystems.

The restoration of dry tropical vegetation is severely limited due to problems associated with the regeneration of tree seedling (i.e., survival, growth and development), which is highly sensitive and most important stage of plant's life (Grubb 1977). It is reported that a change in the regeneration pattern of tree seedlings can influence the plant community structure and composition of dry tropical ecosystems (Wiegand et al. 2006; Van Langevelde et al. 2011; Chaturvedi et al. 2012). It may have serious ecological consequences, particularly under changing climate. Studies suggest that tree-seedling survival and establishment in dry tropical ecosystems are constrained mainly by water availability (Khurana and Singh 2001; Kraaij and Ward 2006; Cardoso et al. 2016), nutrient availability (Bardgett and Wardle 2003; Vadigi and Ward 2013), shade (Gerhardt 1996; Khurana and Singh 2001), and grass competition (Griscom et al. 2014). Therefore, tropical tree species may have considerably poor productivity under resource-limited conditions (e.g., inadequate water, light, and soil nutrients) and under grass competition. Tree seedling traits vary significantly across the dry tropical ecosystems to get adapted with the variability in abiotic and biotic growth regulators (e.g., light, temperature, soil nutrient regimes, distribution and amount of rainfall, and intensity of predation and disturbance) (Jha et al. 2000; Khurana and Singh 2001; Fredericksen 2011; Tripathi and Raghubanshi 2014). However, the complex mechanism that affects the tree species establishment in the dry tropical environments is still unclear (Khurana and Singh 2002). So far, such mechanistic studies have been done with a limited range of species and factors (Kambatuku et al. 2011; Ward and Esler 2011; Tripathi and Raghubanshi 2014). Therefore, a comprehensive understanding of the factors influencing the tree-species-seedling recruitment and the ecology of a set of species representing important plant communities are needed to improve our ability to manage the dry tropical environment and for the prediction of future change in plant community dynamics. The objective of the present study was to identify the seedling survival and growth under individual resources and to observe the interactive effects of various environmental variables (resources and disturbances) on seedling survival and growth in the dry tropical environment (forest and savanna vegetation), based on the available literature. The findings of the study may help to better predict and devise the measures for restoration of dry tropical environment.

\section{Resources and disturbances}

Several abiotic and biotic growth regulators are known to determine the vegetation structure and composition of dry tropical ecosystems, especially via its impact at the seedling stage of the plant (Fig. 2). These can be broadly classified as: (1) resources, such as water (Reich and Borchert 1984; Chaturvedi et al. 2013; Vadigi 2013; Barbosa et al. 2014), light (Ceccon et al. 2006; Tripathi and Raghubanshi 2014), and soil nutrients (Huante et al. 1995; Ceccon et al. 2006; Chaturvedi et al. 2012; Tripathi and Raghubanshi 2014) and (2) disturbances, such as fire (Khurana and Singh 2001; Otterstrom and Schwartz 2006, Pluchon et al. 2014), herbivory (Higgins et al. 2000; Chaturvedi et al. 2012; Norghauer and Newbery 2014; Juan-Baeza et al. 2015; Torres and Renison 2015), grass competition (Riginos 2009; Ortega-Pieck et al. 2011; Griscom et al. 2014), and atmospheric $\mathrm{CO}_{2}$ (Khurana and Singh 2002). A series of experiments have been conducted across the dry tropical environment, which suggest that tree-seedling survival and establishment are highly susceptible to water stress, nutrient shortage, shade, herbivory, and competition with grasses (Table 1). In the later section of this review, we have given a brief insight on the effect of various resources and disturbances individually as well as interactively on tree-seedling growth and establishment to understand the involved ecology for management perspective under dry tropical environment.

\subsection{Water}

Soil water availability is one of the key factor influencing the survival and growth of plant communities in dry tropical ecosystems (Khurana and Singh 2001). Increasing soil water availability promotes the survival and growth rate of juvenile tree seedlings (Khurana and Singh 2004; Yavitt and Wright 2008). However, soil water limitation may increase the seedling mortality (Yavitt and Wright 2008; Bingham and Simard 2011), reduce photosynthesis (Chaves et al. 2002; Ashraf and Harris 2013; Chaturvedi et al. 2013), and increase the vulnerability of forests to fire (Nepstad et al. 2002; Van Mantgem et al. 2013). Dry tropical ecosystem often experiences a drought period of 2-6 months, during which increased water scarcity causes the dehydration or wilting of tree seedlings (Chaves et al. 2002; Khurana and Singh 2004). It intensifies the chances of seedling mortality for the species growing under moist habitats than those of under drier habitats due to better adaptation of later to the water stress (Engelbrecht et al. 2006). Furthermore, extended dry periods during the drought months are found perilous to the survival of tree seedling in the dry tropical ecosystems (Ward and Esler 2011; Comita and Ehgelbrecht 2014). 
Fig. 2 Illustrated representation of key environmental resources and natural disturbances governing tree-seedling survival and growth

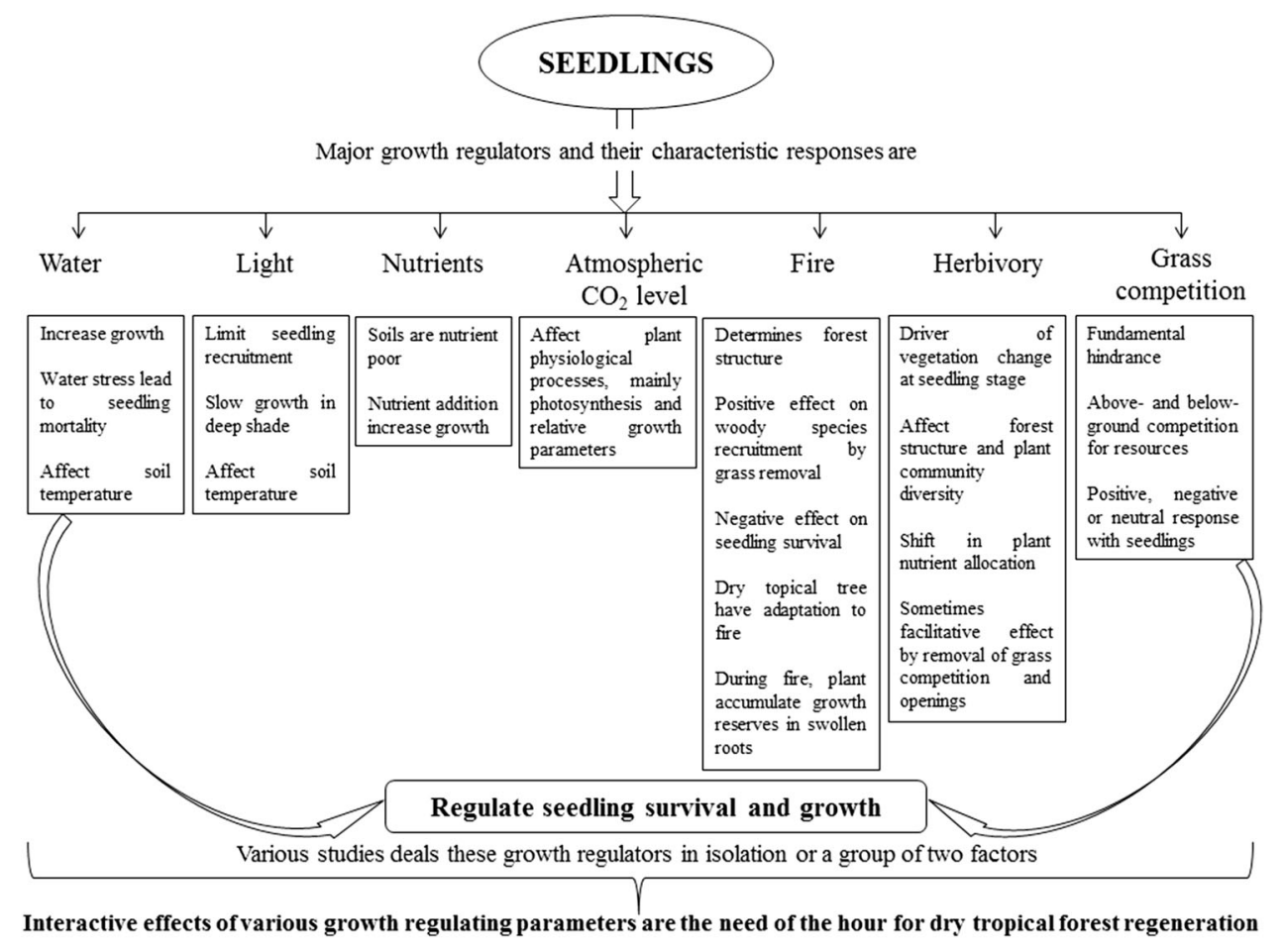

\subsection{Nutrient availability}

The nutrient poor soils of dry tropical environment generally show strong seasonal variability in nutrient release (Singh et al. 1989; Raghubanshi et al. 1990; Singh et al. 2009; Powers et al. 2015). These soils are characterized by the inherent patchy distribution of nutrient and water availability (Roy and Singh 1994; Chaturvedi et al. 2011). This distribution pattern is also governed by many external factors, such as fire, fertilizer addition, herbivore density, and forest degradation (Elmqvist et al. 2007; Balvanera et al. 2011). Water availability and soil nutrient availability are closely interrelated (Van der Waal et al. 2009; Sardans and Peñuelas 2013). In the presence of grasses, an increase in soil nutrient availability induces water stress, which further leads to a lower growth performance in the tree seedlings $(\mathrm{Hu}$ and Schmidhalter 2005, Akınc1 and Lösel 2012). Interestingly, a more constrained seedling establishment is reported under higher soil fertility in dry tropical ecosystems. It is attributed to an increased competition of tree seedlings with grasses for $t$ resources in the soil (Kraaij and Ward 2006; Griscom et al. 2005; Sankaran et al. 2008; Van der Wall et al. 2011; Mills et al. 2013). Therefore, it is imperative to consider the impact of soil nutrients under the combined effect of water and grass competitions on tree species recruitment for a holistic understanding of the drivers of tree-seedling growth.

\subsection{Light}

Light limits the tree-seedling recruitment under various forest canopies (Way and Pearcy 2012), due to its primary importance in photosynthesis. In general, tropical plant species have a wider amplitude of light requirements (Whitmore 1975; Vieira and Scariot 2006a, b; Markesteijn et al. 2007). The importance of light for the growth of trees seedlings of tropical ecosystem has been well documented (Turner 2001; Vieira and Scariot 2006a; Tripathi and Raghubanshi 2014). Seedlings generally grow slowly under high canopy or deep shade relatively utilizes less or no added nutrients to the soil (Baker et al. 2003). However, canopy covering by the adult trees may have certain advantages to the understory seedlings, such as it allows the access to higher soil moisture for longer periods to the tree seedlings (Holmgren et al. 1997; Phillips and Barnes 2002; Bertacchi et al. 2016) due to hydraulic lift (Ludwig et al. 2004) or decreases temperature and evapo-transpiration (Bernhard-Reversat 1982). It has been reported that all benefit at the seedling stage was observed in the light gaps (Augspurger 1984; Huante et al. 1993). It is found that canopy openings created by tree-fall gaps are important sites for the growth and establishment of tree seedlings (Sapkota and Odén 2009). These gaps are characterized by higher levels of light, which leads to an increased seedling recruitment and, thus, higher species diversity (Canham 1988; Schnitzer and Carson 2001; Schnitzer et al. 2008). 
Table 1 Recent studies for tree-seedling growth under different light conditions, fertilizer treatment, water availability, grass competition, and herbivory under dry tropical environments

\begin{tabular}{|c|c|c|c|c|c|c|c|}
\hline Region & $\begin{array}{l}\text { No. of } \\
\text { species }\end{array}$ & $\begin{array}{l}\text { Light (\% full } \\
\text { sunlight) }\end{array}$ & Fertilizer treatment & Water treatment & $\begin{array}{l}\text { Grass } \\
\text { competition }\end{array}$ & Herbivore & References \\
\hline \multirow[t]{4}{*}{ Africa } & 8 & $\begin{array}{l}\text { Full sunlight } \\
\text { versus } 33 \%\end{array}$ & $\begin{array}{l}\text { No fertilizer versus } \\
\text { higher dose of fertilizer }\end{array}$ & $\begin{array}{l}\text { Regular versus } \\
\text { natural rainfall }\end{array}$ & Yes & & $\begin{array}{l}\text { Vadigi and Ward } \\
\text { (2013) }\end{array}$ \\
\hline & 1 & $4,19,38100 \%$ & & $\begin{array}{l}20 \% \text { versus } 100 \% \\
\text { field capacity }\end{array}$ & & & Chirara (2001) \\
\hline & 8 & $\begin{array}{l}\text { Full sunlight } \\
\text { versus } 20 \%\end{array}$ & $\begin{array}{l}\text { No fertilizer versus } \\
\text { higher dose of fertilizer }\end{array}$ & $\begin{array}{l}\text { Regular versus } \\
\text { natural rainfall }\end{array}$ & & & $\begin{array}{l}\text { Barbosa et al. } \\
\text { (2014) }\end{array}$ \\
\hline & 13 & $3.5,11,65 \%$ & No fertilizer versus NPK & & & & $\begin{array}{l}\text { Schumacher et al. } \\
\text { (2008) }\end{array}$ \\
\hline \multirow[t]{6}{*}{ Americas } & 1 & & & & Yes & Yes & $\begin{array}{l}\text { Kambatuku et al. } \\
\text { (2011) }\end{array}$ \\
\hline & 9 & & & & Yes & & $\begin{array}{l}\text { Flory and Clay } \\
\text { (2010) }\end{array}$ \\
\hline & 1 & $\begin{array}{l}\text { Full sunlight } \\
\text { versus } 87 \%\end{array}$ & $\begin{array}{l}\text { No Fertilizer versus } \\
14 \mathrm{~g} \mathrm{~N} \mathrm{~m}^{2}\end{array}$ & & & Yes & $\begin{array}{l}\text { Siemann and } \\
\text { Rogers (2003) }\end{array}$ \\
\hline & 10 & $\begin{array}{l}\text { Full sunlight } \\
\text { versus } \\
\text { understory }\end{array}$ & & & & Yes & Flory et al. (2015) \\
\hline & 18 & $\begin{array}{l}\text { Full sunlight } \\
\text { versus } 26 \%\end{array}$ & $\begin{array}{l}50 \mathrm{ml} \text { of } 1 / 4 \text { strength } \\
\text { Johnson's solution }\end{array}$ & & & & $\begin{array}{l}\text { Hoffmann and } \\
\text { Franco }(2003)\end{array}$ \\
\hline & 6 & $2,37,100 \%$ & & & Yes & & $\begin{array}{l}\text { Celis and Jose } \\
\text { (2011) }\end{array}$ \\
\hline \multirow[t]{3}{*}{$\begin{array}{l}\text { Asia/ } \\
\text { Australia }\end{array}$} & 3 & $10,90 \%$ & $\begin{array}{l}\text { No fertilizer versus } \\
\text { higher dose of fertilizer }\end{array}$ & & & $\begin{array}{l}30,7 \% \text { leaf } \\
\text { damage }\end{array}$ & $\begin{array}{l}\text { Zhao and Chen } \\
\text { (2012) }\end{array}$ \\
\hline & 2 & $\begin{array}{l}\text { Full sunlight } \\
\text { versus } 50 \%\end{array}$ & Low versus high NPK & & & & Zhang et al. (2011) \\
\hline & 5 & $3,25,100 \%$ & $30,60,120 \mathrm{~kg} \mathrm{~N} / \mathrm{ha}$ & & & & $\begin{array}{l}\text { Tripathi and } \\
\text { Raghubanshi } \\
\text { (2014) }\end{array}$ \\
\hline Europe & 1 & & $15,30,45 \mathrm{~g} \mathrm{~N} / \mathrm{m}^{2}$ & Drip irrigation & Yes & & $\begin{array}{l}\text { Van der Waal et al. } \\
\text { (2009) }\end{array}$ \\
\hline
\end{tabular}

These gaps are generally characterized by comparatively greater herbaceous vegetation (Sagar et al. 2012). Such vegetation growth under canopy gaps is attributed to its favorable light and nutrient conditions on one hand and the reduced competition from the tree on the other (Sagar et al. 2008 , 2012). Therefore, studies are required to further elucidate such effects of light on the tree-seedling growth under dry tropical environment in addition to grass competition.

\subsection{Grass competition}

In general, grasses pose severe competition to tree-seedling survival, growth, and establishment (Griscom et al. 2009), mainly by affecting their recruitment (Khurana and Singh 2001; Thaxton et al. 2012). Most of the studies have explained tree-seedling growth with grass in terms of competition for above- (e.g., light) and below-ground resources (e.g., water and nutrients) between them
(Hardwick et al. 2000; Hoffmann and Franco 2003). Grasses suppress the seedling growth of tree species due to the depletion of resources (i.e., water or nutrient) under dry tropical environments (Sankaran et al. 2004; Kambatuku et al. 2011). In a study under dry ecosystems, Donzelli et al. (2013) found that grasses compete more for water, whereas trees are the better competitor for soil nutrients. However, studies highlighting the interactive effects of water, light, nutrients, and grass competition on the survival and growth of tree seedling are limited under dry tropical environment (Gerhardt 1996; Cabin et al. 2000; Tripathi and Raghubanshi 2014).

Several experiments on the tree-seedling growth under grass competition in dry tropics have led to two schools of thoughts, depending upon the level of competition. Some studies showed a positive (Duncan and Chapman 2003; Anthelme and Michalet 2009) or negligible effects of grass presence on tree-seedling growth (Scariot et al. 2008). However, other studies reported negative effects of grass 
presence on growth of tree seedling (Cramer et al. 2007; Hooper et al. 2005; Grellier et al. 2012). Therefore, a dilemma still prevails in the identification of optimal growth condition for various resources under which grass presence either suppresses or facilitates the tree-seedling growth. Tree seedling shows greater mortality during dry season as compared to wet season, which may be attributed to its competition with grasses for nutrient resources (Chirara et al. 1999). On the contrary, under limited or lower resource conditions, grass competition has been reported to have a less negative or even a positive role on the establishment of tree seedling during dry season (Vieira and Scariot 2006a, b; Cardoso et al. 2016). Therefore, field experiments are needed to elucidate these conflicting observations and to understand how grass competition determines the tree recruitment in dry tropical environment under the effect of other set of environmental drivers.

\subsection{Herbivory}

Herbivory is widely recognized as an important driver of changes in vegetation, community structure (i.e., size and composition), and diversity (Augustine and McNaughton 1998; Olff and Ritchie 1998). Several studies reported that herbivory has a strong influence on the plant communities (Becerra 2007; Powers et al. 2015). It influences the plant productivity (Sanchez-Azofeifa et al. 2013; Turcotte et al. 2014) directly by affecting the plants via tissue removal, which results in a shift in plant nutrient allocation (Frost and Hunter 2008; Mikola et al. 2009). However, browsing and grazing have shown differential effects on the treeseedling growth, which may vary significantly with the plant growth stages. It is reported that browsing severely affects the tree species at the juvenile stage, constraining the successful establishment of tree seedling (Campa et al. 1992; Biaou 2009). However, grazing may have an indirect facilitative effect on the tree seedlings via suppressing the grasses and, thus, reducing the later's competitive effect in the dry tropical environment (Pandey and Singh 1992; Ward and Esler 2011; Grellier et al. 2012). In addition, controlled grazing may also have a positive effect (similar to fire) by creating gaps resulting in a better availability of above- and below-ground resources for the tree seedlings, helping in their establishment (Bush and Van Auken 1995; Jeltsch et al. 1996; Kraaij and Ward 2006). However, the impact of herbivory on the tree-seedling survival and the growth under the influence of water or nutrient availability in soil are still unexplored (Derroire et al. 2016).

\subsection{Fire}

Fire is an important factor determining the structure and composition of forest ecosystems (Murphy and Lugo
1986). The dry tropical vegetation are highly susceptible to fire during the drought period, which spans a period of several months (Saha and Hiremath 2003; Kennedy and Fontaine 2009; McDonald et al. 2010). Forest fire has both positive as well as negative impacts on the natural successional processes (Hardwick et al. 2000; Ceccon et al. 2006; Dirzo et al. 2011). The degradation of the dry tropical vegetation by fire encourages the woody regeneration in fields via reducing above-ground grass biomass, which almost eliminates the competitive environment for the growth of tree seedlings (Schultz et al. 1955; Kodandapani et al. 2008). Simultaneously, it also significantly suppresses the pastures growth and regeneration (Powers et al. 2009). The adverse effect of fire on the tree-seedling survival and growth has been well documented in some studies (Du Toit 1972; Hardwick et al. 2000). It greatly impacts the seedlings and juveniles lying on the ground surface (Bond and Keeley 2005). Moreover, the seedlings of dry tropical tree species possess several mechanisms for adaptations to survive or escape from fire mutilation, even under intensive fires. For example, many trees species have tendency to accumulate nutrient and other growth reserves in the underground swollen structures to escape from the influence of fires (Van Langevelde et al. 2003; Wigley et al. 2009; Bond and Parr 2010). On the return of favorable growth conditions, the accumulated reserves further help in the tree-seedling re-growth and establishment (Hoffmann et al. 2004; Wigley et al. 2009).

\subsection{Atmospheric $\mathrm{CO}_{2}$}

The concentration of $\mathrm{CO}_{2}$ in the atmosphere has been consistently increasing, since the industrial revolution and the current $\mathrm{CO}_{2}$ level have reached around $400 \mathrm{ppm}$ (CO2now.org; Bala 2013; Srivastava et al. 2016). The ongoing change in climate with an increase in atmospheric $\mathrm{CO}_{2}$ may strongly affect the tree-seedling survival and growth (Cernusak et al. 2011). In addition, the increased atmospheric $\mathrm{CO}_{2}$ also affects various eco-physiological characteristics (such as photosynthesis, water-use efficiency, and nutrient-use efficiency) of the plants as well as other seedling growth parameters (Khurana and Singh 2004). Most of the studies conducted on the seedling growth in response to atmospheric $\mathrm{CO}_{2}$ in dry tropical environment revealed that relative growth rate (RGR), leaf area ratio (LAR), and total dry weight increase with an increase in the atmospheric $\mathrm{CO}_{2}$ (Khurana and Singh 2002). However, the response to an elevated atmospheric $\mathrm{CO}_{2}$ varies widely among the species (Khurana and Singh 2002; Cernusak et al. 2011). Therefore, future studies should focus on the response of different plant functional groups (such as leguminous vs. non-leguminous, pioneer vs. non-pioneer, and fine-leaved vs. braod-leaved) under 
varying $\mathrm{CO}_{2}$ concentrations to design the appropriate measures to conserve and regenerate the dry tropical forests.

\section{Interactive effects of resources and disturbances on tree-seedling growth and establishment}

Interaction among the various resources and disturbances has been found to regulate the survival, growth, and establishment of the tree seedlings (Rincón and Huante 1993; Khurana and Singh 2001; Ceccon et al. 2006; Tripathi and Raghubanshi 2014). Therefore, a thorough understanding of this interrelationship would help in a better management of the forests in dry tropical ecosystem. A brief account of the interactive effects of major regulatory variables on the seedling growth has been discussed below with a particular emphasis on dry tropical environment.

\subsection{Interactive effect of light availability, nutrient addition, and grass competition}

As stated earlier, the survival and growth of the tree seedlings are intensely determined by light availability (Rincón and Huante 1993; Poorter 2001; Khurana and Singh 2006; Tripathi and Raghubanshi 2014), nutrient availability (Khurana and Singh 2004; Tripathi and Raghubanshi 2014), and grass competition (Ludwig et al. 2004; Grellier et al. 2012) in the dry tropical environments. The plant diversity and distribution are mainly governed by the interaction among these factors in dry tropical ecosystems (see Table 1). Therefore, studies focusing on this complex interaction would help us to understand how dry tropical tree species responds to variable nutrient availability and grass competition across the irradiance levels. In general, nutrient addition significantly affects plant growth in high light availability than the low light availability (Ingestad and McDonald 1989; Rincón and Huante 1993; Tripathi and Raghubanshi 2014). Above- and below-ground resource competition by grasses may suppress the tree-seedling growth under adequate light conditions (Kambatuku et al. 2011). Moreover, grasses have been reported to facilitate the tree-seedling growth via moderating the microclimatic conditions (Vieira and Scariot 2006a, b; Barbosa et al. 2014; Guarino and Scariot 2014). The interactive grass-seedling growth dilemma still prevails, which further gets impetus under the resource variability. Therefore, studies covering tree-seedling growth under grass competition in the effects of nutrients and light are urgently required under the dry tropical environments for a clear understanding and restoration of such vegetation.

\subsection{Interactive effects of water availability, nutrient addition, and grass competition}

Globally, the frequent occurrence of severe droughts has necessitated a thorough understanding of the interaction among the availability of water, nutrient supplementation, and grass competition, particularly in the dry tropical environments (Peñuelas et al.2002; Khurana and Singh 2004; Poorter 2009; Salinas-Peba et al. 2014; Powers et al. 2015). An unpredictable rainfall pattern in dry tropical environment has been indicated in the present climate change forecasts, which may further lead to a greater occurrence of droughts in coming years (IPCC 2007). It is still unclear that how tree seedlings, co-existing with herbaceous vegetation in the dry tropical environments, would respond to the concomitant changes in the availability of soil moisture and nutrients (Hulshof et al. 2013). The current understanding reveals that the relative proportion of woody to delicate herb vegetation is mainly affected by water availability, whereas edaphic (e.g., texture and fertility) and natural disturbance factors (e.g., fire and herbivory) are of minor importance, especially under savanna vegetation (van Langevelde et al. 2003; Sankaran et al. 2008). In general, tree seedlings are negatively affected by the droughts during the moist season, as successful recruitment depends on the continuous water availability (Harrington 1991; Khurana and Singh 2004 Kraaij and Ward 2006; Ferreira et al. 2015). Furthermore, the co-existence of grasses with the woody plants is the characteristic features of dry tropical environments, and therefore, a vigorous competition for light, water, and nutrients exists, specifically in savanna. Such competitions can put an important obstacle in the tree-seedling establishment (Fetene 2003; Flory and Clay 2010). However, it is still a matter of debate that how the intensity of competition between grasses and tree seedlings changes across the water availability in dry tropical environments. Woody cover generally leads to an increase in soil water availability, whereas a decrease in nutrient availability in the dry tropical environment (Sankaran et al. 2008; Sagar et al. 2012).

It is stated that the establishment of woody seedlings in the presence of grass is poorly affected by soil fertility (Cohn et al. 1989; Kraaij and Ward 2006) and enhanced N deposition (Sankaran et al. 2008; Mo et al. 2015; Powers et al. 2015). Limited researches have been done to elucidate that how competitive ability of grass affects the establishment of tree seedlings in interaction with the water and nutrient availabilities (Coomes and Grubb 2000; Maass et al. 1995). This knowledge gap limits the response prediction of woody cover to the concomitant changes in nutrient and water availability in the presence of grasses. Water is considered as the most important intermediary 
resource (Debain et al. 2005), thus, under dry conditions it is supposed to exacerbate the negative effects of fertilizer addition by promoting competition between grasses and the tree seedlings. The increased competition of grasses with seedlings under nutrient-rich conditions has been reported, especially under intermediate or limited water availability which affects the seedling survival and growth (Cohn et al. 1989; Vieira and Scariot 2006a, b). However, further studies are needed to better understand the mechanism underlying such changes.

\subsection{Interactive effects of herbivory, nutrient addition, and grass competition}

Tree-seedling establishment is highly affected by grazers and browsers under different dry tropical forests and savanna. It is attributed to the ingestion of plant tissue and resulting change in soil nutrient condition (due to dung and urine fertilization and erosion-transport by trampling) which affects the competition between tree seedlings and grasses (Scholes and Archer 1997; Griscom et al. 2009). The herbivory may differs with plant functional traits. However, broad scale studies covering a group of tree species for deducing the relationship of the herbivory with tree-seedling establishment are limited in the dry tropical environment (Kraaij and Ward 2006; Gratani et al. 2003; Bonito et al. 2011; Pringle et al. 2012). Understanding the dynamics of seedling establishment of most of the dry tropical tree species with respect to herbivory in the effect of other environmental factors can help to predict the impending changes in the forest vegetation (Vadigi 2013).

It has been found that the success of tree seedlings is mainly controlled by their ability to cope with the herbivory (Becerra 2007; Powers et al. 2015). In addition to its evident negative effects, herbivores may also favor the tree-seedling growth under the dry tropical environment. For example, browsers have been observed to stimulate the shoot development under fertile soil condition (Du Toit et al. 1990; Gerhardt 1998; Santiago et al. 2012; Vadigi and Ward 2013), whereas grazers reduce grass competition and promote the seedling establishment (Briske 1996; Gunaratne et al. 2010). Moreover, ungulate herbivores indirectly regulate the tree community structure and dynamics mainly by their excretal inputs enriching the soil nutrient status (Van der Waal et al. 2011; Juan-Baeza et al. 2015). Such externally added nutrient via herbivores on one hand promotes the growth of tree seedlings, whereas enhances the grass competition on the other and, thus, may reduce seedling establishment (Van der Waal et al. 2009; JuanBaeza et al. 2015).

Grass competition constrains the tree recruitment, mainly under high precipitation conditions (Hau and Corlett 2003; Hooper et al. 2005). On contrary, potential positive effects, such as protection from browsing and grazing, are also exerted by the presence grasses which help in tree-seedling establishment (Seymour 2008; Lagendijk et al. 2011; Vadigi and Ward 2013). Thus, grazers may facilitate the browsing of tree seedlings by eliminating the grasses. Moreover, grazing creates more harms than benefits by removing the grass competition. Furthermore, the interplays between browsers and grazers significantly determine the establishment success of trees in the tropical dry environment via their effect on soil nutrients and grass competition.

\section{Knowledge gaps and future recommendations}

Studies appraising the growth response of individual tree species in relation to resource augmentation and disturbance are well presented (e.g., Ashton and Berlyn 1992; Navas and Garnier 2002; Gratani et al. 2003; Kraaij and Ward 2006; Bonito et al. 2011). However, comparative studies on the tree seedlings of important dry tropical tree species representing different functional groups, within or across the communities, are limited (Khurana and Singh 2001; Sanchez-Azofeifa et al. 2013; Powers et al. 2015). This critically limits our understanding of the dynamics of complex (multi-species) dry tropical forests, where species compete and facilitate each other in growth and establishment. Therefore, it is imperative to understand (1) the response variation of tree seedlings in dry tropical environments for differences in the local environmental (i.e., resources and disturbances) conditions (to explain their relative dominance in varied environmental conditions) and (2) how such response variations relate to functional traits of the studied tree species. The present article identified the following knowledge gaps in the studies on treeseedling growth and establishment: (1) to identify the key determinants of tree-seedling growth under the dry tropical environment, specifically across the functional types, (2) to identify the relative importance of resources on seedling growth under the dry tropical environment, (3) how seedling growth performs under grass competition in the effect of other adjoining resources and disturbances, and (4) identification of adaptive responses of tree seedlings to defoliation or herbivory pressure.

Therefore, studies are required on tree-seedling survival, growth, and establishment under the aforementioned interactions in the dry tropical environment: (1) to fine-tune the management strategy for the conservation and restoration of these dry forests, (2) to improve the limited understanding on competitive inhibition versus resource limitation for their effect on the tree-seedling growth (Kraaij and Ward 2006), (3) to understand how variation in the nutrient availability (both natural and man-made) 


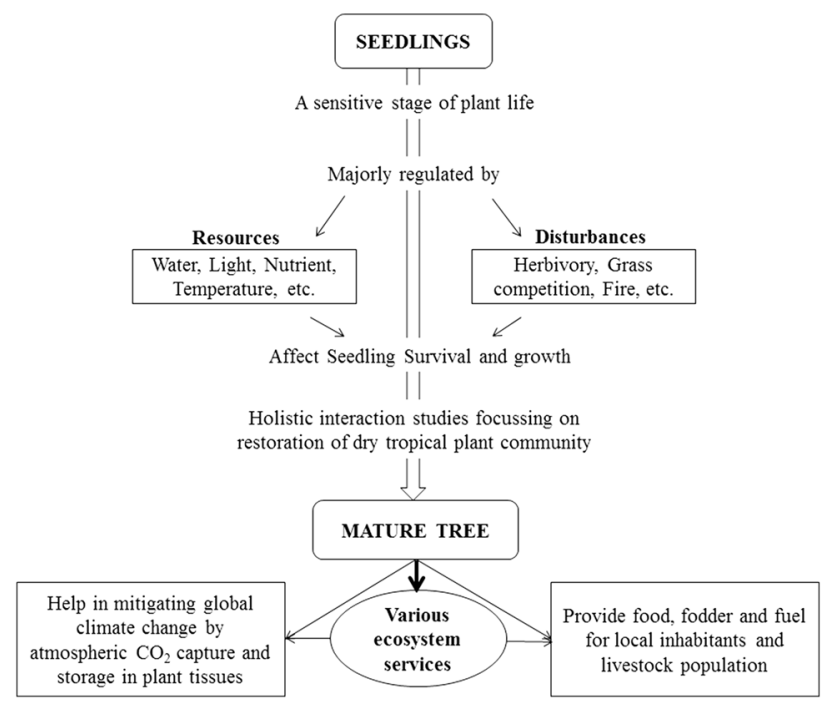

Fig. 3 Conclusive remarks on dry tropical tree-seedling growth strategies by multi-factorial studies for improving the provisioning of ecosystem services

would affect the plant community dynamics under the influence of other set of environmental factors, and (4) to better understand the impacts of widespread human-induced fertilization, watering, and canopy cutting on the dry tropical ecosystems (Fig. 3).

In the dry tropical environment, the knowledge of early survival and growth response of native species tree seedlings under the combinations of temporal variations of nutrient, light, and grass competition is critically required for the management and restoration of dry tropical vegetation. These differences might affect the establishment of native tree species, which may subsequently change the composition and dynamics of dry tropical plant community. Ultimately, it may result in a significant variation in the functional structure of the tropical dry vegetation. However, the regeneration of plant communities in dry tropical environments, with a focus on species and functional group specific responses, would help in improving their provisioning services (Dhyani and Dhyani 2016).

\section{Conclusion}

The dry tropical ecosystems are under tremendous pressure, imposed by the ever-growing human population, which is resulting in their degradation. These degraded ecosystems are majorly comprised of closed-to-open forest and savanna vegetation along with adjacent sparse grasslands and marginal croplands. Seedlings are the most affected stage under these ecosystems, and thus, call for a better management perspective. The present review clearly indicates that the fresh experimental efforts are highly required to understand the interactive effects of various resources (such as light, water, nutrient, etc.) and disturbances (such as defoliation, grass competition, etc.) regimes on tree-seedling recruitment and establishment in dry tropical environment. The outcome might be helpful for the prediction of future community structure of dry tropical forest as well as savanna vegetation, which is continuously facing natural (e.g., herbivory and fire) and anthropogenic (e.g., lopping, climate change, and nitrogen deposition) perturbations. Such interactive studies would provide an improved understanding about the tree-seedling growth, which could be helpful in the management of the dry tropical environment. However, if not managed in a sound manner, the subsequent change in forest community dynamics due to such perturbations may have a considerable impact on global $\mathrm{C}$ cycle and climatic change.

Acknowledgments The authors are highly thankful to Emeritus Prof. J.S. Singh and Dr. Hema Singh, Department of Botany, Institute of Science, Banaras Hindu University, for their valuable suggestions and encouragement. Financial support from University Grants Commission (UGC), Council of Scientific and Industrial Research (CSIR), New Delhi, India and Banaras Hindu University, Varanasi, India is also acknowledged. We also thank the Handling editor and anonymous reviewers for their critical suggestions for improving the article.

Author's contribution ASR and RB proposed the theme of the article. RB, RS, and PS wrote the article in consultation with ASR.

\section{References}

Akıncı Ş, Lösel DM (2012) Plant water-stress response mechanisms. In: Rahman IMM, Hasegawa H (eds) Water stress. Rijeka, Croatia

Anthelme F, Michalet R (2009) Grass-to-tree facilitation in an arid grazed environment (Air Mountains, Sahara). Basic Appl Ecol 5:437-446

Ashraf M, Harris PJC (2013) Photosynthesis under stressful environments: an overview. Photosynthetica 51:163-190

Ashton PM, Berlyn GP (1992) Leaf adaptations of some Shorea species to sun and shade. New Phytol 121:587-596

Augspurger CK (1984) Light requirement of neotropical tree seedlings a comparative study of growth and survival. J Ecol 72:777-795

Augustine DJ, McNaughton SJ (1998) Ungulate effects on the functional species composition of plant communities: herbivore selectivity and plant tolerance. J Wildl Manage 62:1165-1183

Baker TR, Swaine MD, Burslem DFRP (2003) Variation in tropical forest growth rates: combined effects of functional group composition and resource availability. Perspect Plant Ecol Evol Syst 6:21-36

Bala G (2013) Digesting 400 ppm for global mean $\mathrm{CO}_{2}$ concentration. Curr Sci 104:1471

Balvanera P, Quijas S, Pérez-Jiménez A (2011) Distribution patterns of tropical dry forest trees along a mesoscale water availability gradient. Biotropica 43:414-422

Barbosa ERM, van Langevelde F, Tomlinson KW, Carvalheiro LG, Kirkman K, de Bie S, Prins HHT (2014) Tree species from different functional groups respond differently to environmental changes during establishment. Oecologia 174:1345-1357 
Bardgett RD, Wardle DA (2003) Herbivore mediated linkages between aboveground and belowground communities. Ecology $84: 2258-2268$

Becerra JX (2007) The impact of herbivore-plant coevolution on plant community structure. Proc Natl Acad Sci USA 104:7483-7488

Bernhard-Reversat F (1982) Biogeochemical cycle of nitro- gen in a semi-arid savanna. Oikos 38:321-332

Bertacchi MI, Amazonas NT, Brancalion PH, Brondani GE, Oliveira A, Pascoa MA, Rodrigues RR (2016) Establishment of tree seedlings in the understory of restoration plantations: natural regeneration and enrichment plantings. Restoration Ecol 24:100-108

Biaou SSH (2009) Tree recruitment in West African dry woodlands: the interactive effects of climate, soil, fire and grazing. Wageningen Universiteit (Wageningen University)

Bingham MA, Simard SW (2011) Do mycorrhizal network benefits to survival and growth of interior Douglas-fir seedlings increase with soil moisture stress? Ecol Evol 1:306-316

Bond WJ, Keeley JE (2005) Fire as a global 'herbivore': the ecology and evolution of flammable ecosystems. Trends Ecol Evol 20:387-394

Bond WJ, Parr CL (2010) Beyond the forest edge: ecology, diversity and conservation of the grassy biomes. Biol Conserv 143:2395-2404

Bonito A, Varone L, Gratani L (2011) Relationship between acorn size and seedling morphological and physiological traits of Quercus ilex $\mathrm{L}$. from different climates. Photosynthetica 49:75-86

Briske DD (1996) Strategies of plant survival in grazed systems: a functional interpretation. The ecology and management of grazing systems. CAB International, Wallingford, pp 37-67

Bush JK, Van Auken OW (1995) Woody plant growth related to planting time and clipping of a C4 grass. Ecology 76:1603-1609

Cabin RJ, Weller SG, Lorence DH, Flynn TW, Sakai AK, Sandquist D, Hadway LJ (2000) Effects of long-term ungulate exclusion and recent alien species control on the preservation and restoration of a Hawaiian tropical dry forest. Conserv Biol 14:439-453

Campa H, Haufler JB, Beyer DE (1992) Effects of simulated browsing on aspen characteristics and nutritional qualities. J Wildl Manag 56:158-164

Canham CD (1988) Growth and architecture of shade-tolerant trees: response to canopy gaps. Ecology 69:786-795

Cardoso AW, Medina-Vega JA, Malhi Y, Adu-Bredu S, Ametsitsi GK, Djagbletey G, Langevelde F, Veenendaal E, Oliveras I (2016) Winners and losers: tropical forest tree seedling survival across a West African forest-savanna transition. Ecol Evol 6:3417-3429

Ceccon E, Huante P, Rincón E (2006) Abiotic factors influencing tropical dry forests regeneration. Braz arch biol technol 49:305-312

Celis G, Jose S (2011) Restoring abandoned pasture landwith native tree species in Costa Rica: effects of exotic grass competition and light. For Ecol Manag 261:1598-1604

Cernusak LA, Winter K, Martínez C, Correa E, Aranda J, Garcia M, Jaramillo C, Turner BL (2011) Responses of legume versus nonlegume tropical tree seedlings to elevated $\mathrm{CO}_{2}$ concentration. Plant Physiol 157:372-385

Champion HG, Seth SK (1968) General silviculture for India. Government of India, Delhi

Chapin FS III, Rupp TS, Starfield AM, DeWilde L, Zavaleta ES, Fresco N, McGuire AD (2003) Planning for resilience: modeling change in human-fire interactions in the Alaskan boreal forest. Front Ecol Environ 1:255-261

Chaturvedi RK, Raghubanshi AS, Singh JS (2011) Effect of smallscale variations in environmental factors on the distribution of woody species in tropical deciduous forests of Vindhyan Highlands, India. J Bot 2:970-997

Chaturvedi RK, Raghubanshi AS, Singh JS (2012) Effect of grazing and harvesting on diversity, recruitment and carbon accumulation of juvenile trees in tropical dry forests. Forest Ecol Manag 284:152-162

Chaturvedi RK, Raghubanshi AS, Singh JS (2013) Growth of tree seedlings in a tropical dry forest in relation to soil moisture and leaf traits. J Plant Ecol 6:158-170

Chaturvedi RK, Raghubanshi AS, Singh JS (2014) Relative effects of different leaf attributes on sapling growth in tropical dry forest. J Plant Ecol 6:544-558

Chaves MM, Pereira JS, Maroco J, Rodrigues ML, Ricardo CPP, Osório ML, Carvalho I, Faria T, Pinheiro C (2002) How plants cope with water stress in the field? Photosynthesis and growth. Ann Bot 89:907-916

Chazdon RL (2003) Tropical forest recovery: legacies of human impact and natural disturbances. Perspect Plant Ecol Evol Syst 6:51-71

Chirara C (2001) Tree invasion in a semi-arid savanna in Zimbabwe: seedling recruitment of Acacia karroo. Ph.D. Thesis, Utrecht University, The Netherlands

Chirara C, Frost PGH, Gwarazimba VEE (1999) Grass defoliation affects survival and growth of seedlings of Acacia karroo, an encroaching species in southwestern Zimbabwe. Afr J Range Forage Sci 15:41-47

Cohn EJ, Vanauken OW, Bush JK (1989) Competitive interactions between Cynodon dactylon and Acacia smallii seedlings at different nutrient levels. Am Midl Nat 121:265-272

Comita LS, Ehgelbrecht BMJ (2014) Drought as a driver of tropical tree species regeneration dynamics and distribution patterns. In: Coomes DA, Burslem DFRP, Simonson WD (eds) Forests and global change. Cambridge University Press, British Ecological Society, Cambridge

Coomes DA, Grubb PJ (2000) Impacts of root competition in forests and woodlands: a theoretical framework and review of experiments. Ecol Monogr 70:171-207

Cramer MD, Chimphango SBM, van Cauter A, Waldram MS, Bond WJ (2007) Grass competition induces $\mathrm{N}_{2}$ fixation in some species of African Acacia. J Ecol 95:1123-1133

Crews TE, Kitayama K, Fownes JH, Riley RH, Herbert DA et al (1995) Changes in soil phosphorus fractions and ecosystem dynamics across a long chronosequence in Hawaii. Ecology 76:1407-1424

Debain S, Curt T, Lepart J (2005) Indirect effects of grazing on the establishment of Pinus sylvestris and Pinus nigra seedlings in calcareous grasslands in relation to resource level. Ecoscience 12:192-201

Derroire G, Tigabu M, Odén PC, Healey JR (2016) The effects of established trees on woody regeneration during secondary succession in tropical dry forests. Biotropica 48:290-300

Dhyani S, Dhyani D (2016) Significance of provisioning ecosystem services from moist temperate forest ecosystems: lessons from upper Kedarnath valley, Garhwal, India. Energ Ecol Environ 1:109-121

Dirzo R, Young HS, Mooney HA (2011) Seasonally dry tropical forests: ecology and conservation. Island Press, Washington, DC

Donzelli D, De Michele C, Scholes RJ (2013) Competition between trees and grasses for better soil water and mineral nitrogen in dry savannas. J Theoret Biol 332:181-190

$\mathrm{Du}$ Toit PF (1972) The goat in a bush-grass community. Proc Grassland Soc Southern Afr 7:44-50

Du Toit JT, Bryant JP, Frisby K (1990) Regrowth and palatability of Acacia shoots following pruning by African savanna browsers. Ecology 71:149-154 
Duncan RS, Chapman CA (2003) Tree-shrub interactions during early secondary forest succession in Uganda. Restor Ecol 11:198-207

Elmqvist T, Pyykönen M, Tengö M, Rakotondrasoa F, Rabakonandrianina E, Radimilahy C (2007) Patterns of loss and regeneration of tropical dry forest in Madagascar: the social institutional context. PLoS ONE 2:e402

Engelbrecht BMJ, Dalling JW, Pearson TRH, Wolf RL, Gálvez DA, Koehler T, Kursar TA (2006) Short dry spells in the wet season increase mortality of tropical pioneer seedlings. Oecologia 148:258-269

Ferreira WN, Lacerda CFD, Costa RCD, Medeiros Filho S (2015) Effect of water stress on seedling growth in two species with different abundances: the importance of Stress Resistance Syndrome in seasonally dry tropical forest. Acta Bot Bras 29:375-382

Fetene M (2003) Intra-and inter-specific competition between seedlings of Acacia etbaica and a perennial grass (Hyparrenia hirta). J Arid Environ 55:441-451

Flory SL, Clay K (2010) Non-native grass invasion alters native plant composition in experimental communities. Biol Invasions 12:1285-1294

Flory SL, Clay K, Emery SM, Robb JR, Winters, B (2015) Fire and non-native grass invasion interact to suppress tree regeneration in temperate deciduous forests. J Appl Ecol 52:992-1000

Fredericksen TS (2011) Review silviculture in seasonally dry tropical forests. In: Günter S, Weber M, Stimm B, Mosandl R (eds) Silviculture in the tropics. Springer, Berlin, pp 339-360

Frost CJ, Hunter MB (2008) Herbivore-induced shifts in carbon and nitrogen allocation in red oak seedlings. New Phytol 178:835-845

Gerhardt K (1996) Effects of root competition and canopy openness on survival and growth of tree seedlings in a tropical seasonal dry forest. For Ecol Manag 82:33-48

Gerhardt K (1998) Leaf defoliation of tropical dry forest tree seedlings-implications for survival and growth. Trees 13:88-95

Gratani L, Meneghini M, Pesoli P, Crescente MF (2003) Structural and functional plasticity of Quercus ilex seedlings of different provenances in Italy. Trees 17:515-521

Grellier S, Janeau JL, Barot S, Ward D (2012) Grass competition is more important than seed ingestion by livestock for Acacia recruitment in South Africa. Plant Ecol 213:899-908

Griscom HP, Ashton PMS, Berlyn GP (2005) Seedling survival and growth of three native species in pastures: implications for dry forest rehabilitation. For Ecol Manag 218:306-318

Griscom HP, Griscom BW, Ashton MS (2009) Forest regeneration from pasture in the dry tropics of Panama: effects of cattle, exotic grass, and forested riparia. Restor Ecol 17:117-126

Griscom B, Ellis P, Putz FE (2014) Carbon emissions performance of commercial logging in East Kalimantan, Indonesia. Global Change Biol 20:923-937

Grubb PJ (1977) The maintenance of species richness in plant communities: the importance of the regeneration niche. Biol Rev 52:107-145

Guarino EDSG, Scariot A (2014) Direct seeding of dry forest tree species in abandoned pastures: effects of grass canopy and seed burial on germination. Ecol Res 29:473-482

Gunaratne AMTA, Gunatilleke CVS, Gunatilleke IAUN, Madawala Weerasinghe HMSP, Burslem DFRP (2010) Barriers to tree seedling emergence on human-induced grasslands in Sri Lanka. J Appl Ecol 47:157-165

Hardwick KA, Healey JR, Blakesley D (2000) Research needs for the ecology of natural regeneration of seasonally dry tropical forests in Southeast Asia. In: Elliot S, Kerby J, Blakesley D, Hardwick $\mathrm{K}$, Woods K, Anusarnsunthorn (eds) Forest restoration for wildlife conservation. Chiang Mai University, Chiang Mai, pp $165-180$

Harrington GN (1991) Effect of soil moisture on shrub seedling survival in a semi-arid grassland. Ecology 72:1138-1149

Hau BC, Corlett RT (2003) Factors affecting the early survival and growth of native tree seedlings planted on a degraded hillside grassland in Hong Kong, China. Restor Ecol 11:483-488

Higgins SI, Bond WJ, Trollope WSW (2000) Fire, resprouting and variability: a recipe for grass-tree coexistence in savanna. J Ecol 88:213-229

Hoffmann WA, Franco AC (2003) Comparative growth analysis of tropical forest and savanna woody plants using phylogenetically independent contrasts. J Ecol 91:475-484

Hoffmann WA, Orthen B, Franco AC (2004) Constraints to seedling success of savanna and forest trees across the savanna-forest boundary. Oecologia 140:252-260

Holdridge LR (1967) Life zone ecology. Tropical Science Center, San Jose

Holmgren M, Scheffer M, Huston MA (1997) The interplay of facilitation and competition in plant communities. Ecology 78:1966-1975

Hooper E, Legendre P, Condit R (2005) Barriers to forest regeneration of deforested and abandoned land in Panama. J Appl Ecol 42:1165-1174

$\mathrm{Hu}$ Y, Schmidhalter U (2005) Drought and salinity: a comparison of their effects on mineral nutrition of plants. J Plant Nutr Soil Sci 168:541-549

Huante P, Rincon E, Allen EB (1993) Effect of vesiculararbuscular mycorrhizae on seedling growth of four tree species from the tropical deciduous forest in Mexico. Mycorrhiza 2:141-145

Huante P, Rincón E, Acosta I (1995) Nutrient availability and growth rate of 34 woody species from a tropical deciduous forest in Mexico. Funct Ecol 1:849-858

Hubbell SP, Foster RB (1983) Diversity of canopy trees in a neotropical forest and implications for conservation. In: Sutton SL, Whitmore TC, Chadwick AC (eds) Tropical Rain forest: ecology and Management. Blackwell Scientific Publications, Oxford, pp 25-41

Hulshof CM, Martínez-Yrízar A, Burquez A, Boyle B, Enquist BJ (2013) Plant functional trait variation in tropical dry forests: a review and synthesis. Tropical dry forests in the Americas: ecology, conservation, and management. CRC Press, Boca Raton, pp 129-140

Ingestad T, McDonald AJS (1989) Interaction between nitrogen and photon flux density in birch seedlings at steady-state nutrition. Physiol Plants 77:1-11

IPCC (2007) Climate change 2007: impacts, adaptation and vulnerability. Contribution of Working Group II to the Fourth Assessment Report of the Intergovernmental Panel on Climate Change. Cambridge University Press, Cambridge

Jeltsch F, Milton SJ, Dean WRJ, van Rooyen N (1996) Tree spacing and coexistence in semiarid savannas. J Ecol 84:583-595

Jha CS, Singh JS (1990) Composition and dynamics of dry tropical forest in relation to soil texture. J Veg Sci 1:609-614

Jha AK, Arvind S, Singh AN, Singh JS (2000) Evaluation of direct seeding of tree species as a means of revegetation of coal mine spoils. Indian For 126:1217-1221

Juan-Baeza I, Martínez-Garza C, del-Val E (2015) Recovering more than tree cover: herbivores and herbivory in a restored tropical dry forest. PLoS ONE 10:e0128583. doi:10.1371/journal.pone. 0128583

Kambatuku JR, Cramer MD, Ward D (2011) Savanna tree-grass competition is modified by substrate type and herbivory. J Veg Sci 22:225-237 
Kennedy PL, Fontaine JB (2009) Synthesis of knowledge on the effects of fire and fire surrogates on wildlife in US dry forests. JFSP Research Project Reports. Paper 124

Khurana E, Singh JS (2001) Ecology of tree seed and seedlings: implications for tropical forest conservation and restoration. Curr Sci 80:748-757

Khurana E, Singh JS (2002) Ecology of seed and seedling growth for conservation and restoration of tropical dry forest: a review. Environ Cons 28:39-52

Khurana E, Singh JS (2004) Germination and seedling growth of five tree species from tropical dry forest in relation to water stress: impact of seed size. J Trop Ecol 20:385-396

Khurana E, Singh JS (2006) Impact of life-history traits on response of seedlings of five tree species of tropical dry forest to shade. J Trop Ecol 22:653-661

Kodandapani N, Cochrane MA, Sukumar R (2008) A comparative analysis of spatial, temporal, and ecological characteristics of forest fires in seasonally dry tropical ecosystems in the Western Ghats, India. For Ecol Manag 256:607-617

Kottek M, Grieser J, Beck C, Rudolf B, Rubel F (2006) World map of the Köppen-Geiger climate classification updated. Meteorol $\mathrm{J}$ 15:259-263

Kraaij T, Ward D (2006) Effects of rain, nitrogen, fire and grazing on tree recruitment and early survival in bush-encroached savanna. S Afr Plant Ecol 186:235-246

Lagendijk DG, Mackey RL, Page BR, Slotow R (2011) The effects of herbivory by a mega-and mesoherbivore on tree recruitment in Sand Forest, South Africa. PLoS ONE 6:p.e17983

Ludwig F, Dawson TE, Prins HHT, Berendse F, de Kroon H (2004) Below-ground competition between trees and grasses may overwhelm the facilitative effects of hydraulic lift. Ecol Lett 7:623-631

Maass J, Vose JM, Swank WT, Martínez-Yrízar A (1995) Seasonal changes of leaf area index (LAI) in a tropical deciduous forest in west Mexico. For Ecol Manag 74:171-180

Markesteijn L, Poorter L, Bongers F (2007) Light-dependent leaf trait variation in 43 tropical dry forest tree species. Am J Bot 94:515-525

McDonald MA, McLaren KP, Newton AC (2010) What are the mechanisms of regeneration post-disturbance in tropical dry forest? CEE review 07-013 (SR37). Environmental Evidence. www.environmentalevidence.org/SR37.html

Mikola J, Setälä H, Virkajärvi P, Saarijärvi K, Ilmarinen K, Voigt W, Vestberg M (2009) Defoliation and patchy nutrient return drive grazing effects on plant and soil properties in a dairy cow pasture. Ecol Monog 79:221-244

Mills AJ, Milewski AV, Rogers KH, Witkowski ET, Stalmans M (2013) Boundary of treeless grassland in relation to nutrient content of soils on the Highveld of South Africa. Geoderma 200:165-171

Mo Q, Zou B, Li Y, Chen Y, Zhang W, Mao R, Ding Y, Wang J, Lu X, Li X, Tang J (2015) Response of plant nutrient stoichiometry to fertilization varied with plant tissues in a tropical forest. Sci Rep 5:14605

MoEF (1999) National Policy and macrolevel action strategy on biodiversity, ministry of environment and forests. Government of India, New Delhi

Morris RJ (2010) Anthropogenic impacts on tropical forest biodiversity: a network structure and ecosystem functioning perspective. Phil Trans R Soc B 365(1558):3709-3718

Murphy PG, Lugo AE (1986) Ecology of tropical forest. Ann Rev Ecol Evol Syst 17:67-88

Navas ML, Garnier E (2002) Plasticity of whole plant and leaf traits in Rubia peregrina in response to light, nutrient and water availability. Acta Oecol 23:375-383
Nepstad DC, Moutinho P, Dias-Filho MB, Davidson E, Cardinot G, Markewitz D et al (2002) The effects of partial throughfall exclusion on canopy processes, aboveground production, and biogeochemistry of an Amazon forest. J Geoph Res 107(D20):8085

Norghauer JM, Newbery DM (2014) Herbivores differentially limit the seedling growth and sapling recruitment of two dominant rain forest trees. Oecologia 174:459-469

Olff H, Ritchie ME (1998) Effects of herbivores on grassland plant diversity. Trends Ecol Evol 13:261-265

Olivares E, Medina E (1992) Water and nutrient relations of woody perennials from tropical dry forests. J Veg Sci 3:383-392

Ortega-Pieck A, López-Barrera F, Ramírez-Marcial N, García-Franco JG (2011) Early seedling establishment of two tropical montane cloud forest tree species: the role of native and exotic grasses. Fort Ecol Manag 261:1336-1343

Otterstrom SM, Schwartz MW (2006) Responses to Fire in selected tropical dry forest trees. Biotropica 38:592-598

Pandey CB, Singh JS (1992) Influence of rainfall and grazing on belowground dynamics in a dry tropical savanna. Can $\mathrm{J}$ of Bot 70:1885-1890

Peñuelas J, Filella I, Comas P (2002) Changed plant and animal life cycles from 1952-2000 in the Mediterranean region. Global Change Biol 8:531-544

Phillips PL, Barnes PW (2002) Spatial asymmetry in tree-shrub clusters in a subtropical savanna. Am Midl Nat 149:59-70

Pluchon N, Gundale MJ, Marie-Charlotte N, Kardo P, Wardle DA (2014) Stimulation of boreal tree seedling growth by woodderived charcoal: effects of charcoal properties, seedling species and soil fertility. Funct Ecol 28:766-775

Popradit A, Srisatit T, Kiratiprayoon S, Yoshimura J, Ishida A, Shiyomi M, Murayama T, Chantaranothai P, Outtaranakorn S, Phromma I (2015) Anthropogenic effects on a tropical forest according to the distance from human settlements. Sci Rep 5:14689

Powers JS, Becknell JM, Irving J, Pèrez-Aviles D (2009) Diversity and structure of regenerating tropical dry forests in Costa Rica: Geographic patterns and environmental drivers. Forest Ecol Manag 258:959-970

Powers JS, Becklund KK, Gei MG, Iyengar SB, Meyer R, O'Connell $\mathrm{CS}$ et al (2015) Nutrient addition effects on tropical dry fores ts: a mini-review from microbial to ecosystem scales. Front Earth Sci 3:34

Poorter L (2009) Leaf traits show different relationships with shade tolerance in moist versus dry tropical forests. New Phytol 181:890-900

Poorter L (2001) Light-dependent changes in biomass allocation and their importance for growth of rain forest tree species. Funct Ecol 15:113-123

Pringle EG, Dirzo R, Gordon DM (2012) Plant defense, herbivory, and the growth of Cordia alliodora trees and their symbiotic Azteca ant colonies. Oecologia 170:677-685

Raghubanshi AS, Tripathi A (2009) Effect of disturbance, habitat fragmentation and alien invasive plants on floral diversity in dry tropical forests of Vindhyan highland: a review. Trop Ecol 50:57-69

Raghubanshi AS, Srivastava SC, Singh RS, Singh JS (1990) Nutrient release in leaf litter. Nature 346:227

Raven PH, Linda RB, Johnson GB (1993) International edition environment. Saunders College Publishing, Harcourt Brace Jovanovich College Publishers, New York, pp 94-95, 377 and 379

Reich PB, Borchert R (1984) Water stress and tree phenology in a tropical dry forest in the lowlands of Costa Rica. J Ecol 72:61-74

Riginos C (2009) Grass competition suppresses savanna tree growth across multiple demographic stages. Ecology 90:335-340 
Rincón E, Huante P (1993) Growth responses of tropical deciduous tree seedlings to contrasting light conditions. Trees 7:202-207

Roy S, Singh JS (1994) Consequences of habitat heterogeneity for availability of nutrient in a dry tropical forest. J Ecol 82:503-509

Russell-Smith J, Yates C, Edwards A, Allan GE, Cook GD, Cooke P, Craig R, Heath B, Smith R (2003) Contemporary fire regimes of northern Australia, 1997-2001: change since Aboriginal occupancy, challenges for sustainable management. Int J Wildl Fire 12:283-297

Sagar R, Singh A, Singh JS (2008) Differential effect of woody plant canopies onspecies composition and species diversity of ground vegetation: a case study. Trop Ecol 49:189-197

Sagar R, Pandey A, Singh JS (2012) Composition, species diversity, and biomass of theherbaceous community in dry tropical forest of northern India in relation to soilmoisture and light intensity. Environmentalist 32:485-493

Saha S, Hiremath A (2003) Anthropogenic fires in India: a tale of two forests. Arid Lands Newsletter 54

Salinas-Peba L, Parra-Tabla V, Campo J, Munguía-Rosas MA (2014) Survival and growth of dominant tree seedlings in seasonally tropical dry forests of Yucatan: site and fertilization effects. J Plant Ecol 7:470-479

Sanchez-Azofeifa GA, Kalacska M, Quesada M, Calvo-Alvarado JC, Nassar JM, Rodriguez JP (2005) Need for integrated research for a sustainable future in tropical dry forests. Conserv Biol 19:285-286

Sanchez-Azofeifa A, Powers JS, Fernandes GW, Quesada M (2013) Tropical dry forests in the Americas: ecology, conservation, and management. CRC Press, Boca Raton

Sankaran M, Ratnam J, Hanan NP (2004) Tree-grass co-existence in savannas revisited: insights from an examination of assumptions and mechanisms invoked in existing models. Ecol Lett 7:480-490

Sankaran M, Ratnam J, Hanan N (2008) Woody cover in African savannas: the role of resources, fire and herbivory. Global Ecol Biogeogr 17:236-245

Santiago LS, Wright SJ, Harms KE, Yavitt JB, Korine C, Garcia MN, Turner BL (2012) Tropical tree seedling growth responses to nitrogen, phosphorus and potassium addition. $\mathrm{J}$ Ecol 100:309-316

Sapkota IP, Odén PC (2009) Gap characteristics and their effects on regeneration, dominance and early growth of woody species. J Plant Ecol 2:21-29

Sardans J, Peñuelas J (2013) Plant-soil interactions in Mediterranean forest and shrublands: impacts of climatic change. Plant Soil 365:1-33

Scariot A, Vieira DL, Sampaio AB, Guarino E, Sevilha A (2008) Recruitment of dry forest tree species in central Brazil pastures. In: Myster RW (ed) Post-agricultural succession in the neotropics. Springer, New York, NY, pp 231-244

Schnitzer SA, Carson WP (2001) Treefall gaps and the maintenance of species diversity in a tropical forest. Ecology 82:913-919

Schnitzer SA, Mascaro J, Carson WP (2008) Treefall gaps and the maintenance of plant species diversity in tropical forests. Tropical forest community ecology. Blackwell, Chichester, pp 196-209

Scholes RJ, Archer SR (1997) Tree-grass interactions in savannas. Ann Rev Ecol Evol Syst 28:517-544

Schultz AM, Launchbauch JL, Biswell HH (1955) Relationship between grass density and brush seedling survival. Ecology 36:226-238

Schumacher E, Kueffer C, Tobler M, Gmur V, Edwards PJ, Dietz H (2008) Influence of drought and shade on seedling growth of native and invasive trees in the Seychelles. Biotrop. doi:10.1111/ j.1744-7429.2008.00407.x
Seymour CL (2008) Grass, rainfall and herbivores as determinants of Acacia erioloba (Meyer) recruitment in an African savanna. Plant Ecol 197:131-138

Sharma GP, Singh JS, Raghubanshi AS (2005) Plant invasions: emerging trends and future implications. Curr Sci 88:726-734

Siemann E, Rogers WE (2003) Changes in light and nitrogen availability under pioneer trees may indirectly facilitate tree invasions of grasslands. J Ecol 91:923-931

Singh N, Ranade A (2010) The wet and dry spells across India during 1951-2007. J Hydrometeorology 11:26-45

Singh KP, Singh JS (1988) Certain structural and functional aspects of dry tropical forests and savanna. Int $\mathrm{J}$ Ecol Environ Sci 14:31-45

Singh JS, Raghubashi AS, Singh RS, Srivastava SC (1989) Microbial biomass acts as a source of plant nutrients in dry tropical forest and savanna. Nature 338:499-500

Singh JS, Singh KP, Agrawal M (1991) Environmental degradation of the Obra-Renukoot-Singrauli area, India and its impact on natural and derived ecosystems. Environmentalist 11:171-180

Singh JS, Singh DP, Kashyap AK (2009) A comparative account of the microbial biomass- $\mathrm{N}$ and $\mathrm{N}$-mineralization of soils under natural forest, grassland and crop field from dry tropical region, India. Plant Soil Environ 55:223-230

Srivastava P, Singh R, Tripathi S, Singh H (2016) Soil carbon dynamics and climate change: current agro-environmental perspectives and future dimensions. Energy Ecol Environ. doi:10.1007/s40974-016-0024-9

Staver AC, Bond WJ, Stock WD, Van Rensburg SJ, Waldram MS (2009) Browsing and fire interact to suppress tree density in an African savanna. Ecol Appl 19:1909-1919

Thaxton JM, Cordell S, Cabin RJ, Sandquist DR (2012) Non-native grass removal and shade increase soil moisture and seedling performance during hawaiian dry forest restoration. Restor Ecol 20:475-482

Torres RC, Renison D (2015) Effects of vegetation and herbivores on regeneration of two tree species in a seasonally dry forest. J Arid Environ 121:59-66

Tripathi SN, Raghubanshi AS (2014) Seedling growth of five tropical dry forest tree species in relation to light and nitrogen gradients. J Plant Ecol 7:250-263

Turcotte MM, Thomsen CJ, Broadhead GT, Fine PV, Godfrey RM, Lamarre G, Meyer ST, Richards LA, Johnson MT (2014) Percentage leaf herbivory across vascular plant species. Ecology 95:788

Turner IM (2001) The ecology of trees in the tropical rain forest. Cambridge University Press, Cambridge

Vadigi S (2013) Factors affecting savanna tree sapling recruitment. Ph.D. Thesis, University of KwaZulu-Natal Pietermaritzburg

Vadigi S, Ward D (2013) Shade, nutrients, and grass competition are important for tree sapling establishment in a humid savanna. Ecosphere 4: art142

Van der Waal C, De Kroon H, De Boer F, Heitkönig IMA, Skidmore AK, De Knegt HJ, Van Langevelde F, Van Wieren SE, Grant RC, Page BR, Slotow R, Kohi EM, Mwakiwa E, Prins HHT (2009) Water and nutrients alter herbaceous competitive effects on tree seedlings in a semi-arid savanna. J Ecol 97:430-439

Van der Waal C, Kool A, Meijer SS, Kohi E, Heitkonig IMA, de Boer WF, van Langevelde F, Grant RC, Peel MJS, Slotow R, de Knegt HJ, Prins HHT, de Kroon H (2011) Large herbivores may alter vegetation structure of semi-arid savannas through soil nutrient mediation. Oecologia 165:1095-1107

Van Langevelde F, Van de Vijver C, Kumar L, Van de Koppel J, De Ridder N, Van Andel J, Skidmore AK, Hearne JW, Stroosnijder L, Bond WJ, Prins HHT, Rietkerk M (2003) Effects of fire and herbivory on the stability of savanna ecosystems. Ecology $84: 337-350$ 
Van Langevelde F, Tomlinson KW, Barbosa ER, de Bie S, Prins HHT, Higgins SI (2011) Understanding tree-grass coexistence and impacts of disturbances and resource variability in savannas. In: Hill M, Hanan N (eds) Ecosystem function in savannas. CRC Press, Boca Raton, pp 257-271

Van Mantgem PJ, Nesmith JCB, Keifer M, Knapp EE, Flint A, Flint L (2013) Climatic stress increases forest fire severity across the western United States. Ecol Lett 16:1151-1156

Vieira DLM, Scariot A (2006a) Principles of natural regeneration of tropical dry forests for restoration. Restor Ecol 14:11-20

Vieira DLM, Scariot A (2006b) Effects of logging, liana tangles and pasture on seed fate of dry forest tree species in Central Brazil. For Ecol Manag 230:197-205

Ward D, Esler KJ (2011) What are the effects of substrate and grass removal on recruitment of Acacia mellifera seedlings in a semiarid environment? Plant Ecol 212:245-250

Way DA, Pearcy RW (2012) Sunflecks in trees and forests: from photosynthetic physiology to global change biology. Tree Physiol 32:1066-1081

Whitmore TC (1975) Tropical rain forest of far East. Claredon Press, Oxford
Wiegand K, Saltz D, Ward D (2006) A patch dynamics approach to savanna dynamics and bush encroachment insights from an arid savanna. Persp Plant Ecol Evol Syst 7:229-242

Wigley BJ, Bond WJ, Hoffmann MT (2009) Thicket expansion in a South African savanna under divergent land use: local vs. global drivers? Global Change Biol 16:964-976

Wilson EO (1988) Biodiversity. National Academy Press, Washington, DC

Yavitt JB, Wright SJ (2008) Seedling growth responses to water and nutrient augmentation in the understorey of a lowland moist forest, Panama. J Trop Ecol 24:19-26

Zhang Y, Ma X, Zhou Z (2011) The influence of light conditions and interspecific competition on the root foraging traits and seedling growth of two tree species. Plant Biosyst 146:7-14

Zhao J, Chen J (2012) Interspecific variation in compensatory regrowth to herbivory associated with soil nutrients in three ficus (Moraceae) Saplings. Plos One 7(9):e45092. doi:10.1371/ journal.pone.0045092 